\title{
Investigation of In Vivo Antipyretic Activity of Thottea dependens leaves
}

\author{
Ahmed QU, Radhiyah I, Siti Zaiton MS \\ Department of Pharmaceutical Chemistry, Kulliyyah of Pharmacy, International Islamic University Malaysia \\ (IIUM), 25200 Kuantan, Pahang DM, Malaysia
}

\begin{abstract}
Introduction: Leaves of Thottea dependens have been used as folk medicine in Malaysia for the treatment of several conditions involving pain and inflammation with accompanying pyrexia. However, there is no scientific evidence for its effectiveness to treat fever. Hence, the purpose of this study was to evaluate the anti-pyretic activity of methanol $(\mathrm{MeOH})$ and aqueous (Aq) extracts of $T$. dependens leaves in albino mice (ICR strain). Methods: Thirty-six albino mice of both sexes, randomized into six groups $(n=6)$ were used. Group I served as the control and received only the vehicle, normal saline. Group II received paracetamol $150 \mathrm{mg} / \mathrm{kg}$ body weight (b.w.) orally, groups III and IV received 100 and $200 \mathrm{mg} / \mathrm{kg}$ b.w. of the $\mathrm{MeOH}$ extract while groups V and VI received 100 and $200 \mathrm{mg} / \mathrm{kg}$ b.w. of the Aq extract orally. Pyrexia was induced by a subcutaneous injection of $10 \mathrm{~mL} / \mathrm{kg}$ b.w. of $15 \%(\mathrm{w} / \mathrm{v})$ yeast suspended in $0.5 \%(\mathrm{w} / \mathrm{v})$ methylcellulose solution. $\mathrm{LD}_{50}$ of both extracts were determined according to the method of Organisation for Economic Co-operation and Development guidelines. Phytochemical screening was carried out qualitatively for the presence of different class of biologically active compounds. Results: $\mathrm{LD}_{50}$ values for both extracts were found to be greater than $1000 \mathrm{mg} / \mathrm{kg}$ b.w. indicating the wide margin of safety of $T$. dependens leaves. The $\mathrm{MeOH}$ extract at $200 \mathrm{mg} / \mathrm{kg} \mathrm{b}$. w. showed statistically significant $(P<0.01)$ dose dependent reduction of brewer's yeast induced pyrexia in albino mice. Flavonoids, saponins and phenolic compounds were found to be major biologically active phytoconstituents in $\mathrm{MeOH}$ extract. Conclusion: The study showed that $T$. dependens leaves possess significant anti-pyretic activity, thus justifying its ethnomedicinal use in Malaysia to treat fever.
\end{abstract}

KEYWORDS: Thottea dependens, Brewer's yeast induced pyrexia, albino mice

\section{INTRODUCTION}

Fever or pyrexia, is a common symptom of many illnesses and occurs in up to $75 \%$ of adults who are extremely sick as well as in children. It occurs in 19\% to $30 \%$ paediatric emergency visits, and these are always associated with great panic among parents. ${ }^{1}$ Non-steroidal anti-inflammatory drugs (NSAIDs) are currently the most popular antipyretics drugs which includes acetaminophen, aspirin and celecoxib. However, these drugs have been reported to manifest many harmful side effects. Gastric irritation, ulcers and bleeding of the stomach mucosa may occur following long term exposure to the NSAIDs. ${ }^{2,3}$ In addition, acetaminophen has been reported to show toxicity to the liver at a dose slightly above the therapeutic dose. ${ }^{4}$ Selective cyclooxegenase-2 (COX-2) inhibitors

Corresponding author:

Qamar Uddin Ahmed, PhD;

Department of Pharmaceutical Chemistry,

Kulliyyah of Pharmacy,

International Islamic University Malaysia (IIUM),

25200 Kuantan, Pahang DM, Malaysia;

Email: quahmed@iium.edu.my;

Tel: +609-5714932; Fax: +6-095706775 namely celecoxib, valdecoxib and rofecoxib have been reported to display increased cardiovascular risk along with several other side effects including insomnia, abdominal pain, flatulence, headache, nausea and diarrhoea. Hence, valdecoxib and rofecoxib were removed from the market in 2004 and 2005, respectively, due to their excessively increased risk for strokes and heart attacks with long term use. ${ }^{5}$ In respect of the aforementioned side effects, research on the discovery of new antipyretic agents that are safe, more effective and affordable is highly encouraged. ${ }^{6}$ Medicinal plants found in our environment should be the best solution to tackle this problem with respect to discover new and safe antipyretic agents. Plant based medicines used by the population are generally considered as cheaper alternatives to conventional orthodox medicines. ${ }^{7}$ Herbal medicines are booming in the current era and are regarded as important to the public as well as to the scientific community. ${ }^{8}$

The World Health Organization (WHO) reported that $70 \%$ to $80 \%$ of the world population depend on mainly on herbal sources for their primary medicines and almost $80 \%$ of Asian populations use herbal therapies to maintain their health and fight against many disorders. ${ }^{9}$ According to the WHO, nearly $25 \%$ of current drugs prescribed in the United States of America have been derived from different plants. No less than 7,000 medicinal compounds in the modern Volume 14 Number 2, Dec 2015 
pharmacopoeia are based on natural products and among the 120 active compounds have currently been isolated from the higher plants and extensively used in modern medicine today, $80 \%$ display a affirmative correlation between their modern therapeutic use and the traditional use of the plants from which they are derived. ${ }^{10,11}$ Plant derived medicines have many benefits, being relatively safer and affordable as well as their use for the treatment of various ailments. ${ }^{12}$

One such plant used traditionally in the treatment of conditions involving pyrexia is Thottea dependens (Planch.) Klotzsch (or locally known as Telinga Beruang). It is an erect shrub that belongs to the family known as Aristolochiaceae. It is up to $2 \mathrm{~m}$ tall and smooth. The leaves are elliptical or obovate in shape, with a size of $12-29 \mathrm{~cm} \times 5-15 \mathrm{~cm}$, acuminate apex, hairless above, hairy beneath and with 2 pair basal veins.

The bark is rubefacient in nature. T. dependens is used by Temuan Tribe in Malaysia to treat fever. The leaves are pounded for skin complaints and rubbed behind ear to treat fever. ${ }^{13,14}$ In this study, we set out to investigate the anti-pyretic activity of $T$. dependens with a view to establishing a basis for its use in conditions involving pyrexia of different causes. An extensive search of the literature revealed no scientific reports on the antipyretic activity of this plant. Hence, present investigation was an attempt to scientifically prove the traditional claim of the anti-pyretic effect of $T$. dependen sleaves through estimation of its in vivo antipyretic effect of methanolic and aqueous extracts of the leaves using mice.

\section{MATERIAL AND METHODS}

\section{Collection and identification of plant material}

Fresh leaves $(7 \mathrm{~kg})$ of $T$. dependens were collected from Tasik Kenyir located in the state of Terengganu, Malaysia and authenticated by Dr. Norazian Hassan (Taxonomist), Kulliyyah of Pharmacy, IIUM. The voucher specimen (NMPC-QRI414) has been deposited in the herbarium of KOP for future reference.

Preparation of methanolic (MeOH) and aquoues (Aq) extracts of $T$. Dependen sleaves

The leaves $(7 \mathrm{~kg})$ were first inspected for deterioration and the presence of foreign materials and then dried in a PROTECH laboratory air dryer (FDD-720-Malaysia) at $40^{\circ} \mathrm{C}$ for 2 days and powdered through Fritsch Universal Cutting Mill-PULVERISETTE 19-Germany to get $750 \mathrm{~g}$ dried powder. It was then stored in a desiccator at $2{ }^{\circ} \mathrm{C}$ until further use..$^{15}$

For the preparation of methanolic extract $(\mathrm{MeOH})$, the coarsely grounded dry powder [0.5 kg] was taken and subjected to maceration extraction process for 3 cycles (each $24 \mathrm{~h}$ soaking) of methanol extraction at room temperature followed by 4 cycles of heat under reflux ( $2 \mathrm{~h}$ each) over boiling water bath. The extract was filtered and concentrated through rotary evaporator (Buchi Rotary Evaporator, R-210, Switzerland) to yield $40 \mathrm{~g}(8 \%) \mathrm{MeOH}$ extract upon freeze drying process. ${ }^{15}$
For the preparation of aqueous extract, $0.2 \mathrm{~kg}$ powdered (pulverized) material was soaked in $2 \mathrm{~L}$ of sterile double-distilled water in a tightly closed round bottom flask at room temperature for a period of $24 \mathrm{~h}$ and filtered through Buchner funnel. The whole process was repeated three times and further heated at 95 ${ }^{\circ} \mathrm{C}$ on water bath for $2 \mathrm{~h}$ to ensure maximum yield of water soluble compounds. The extract was freezedried to give a final yield of $20 \mathrm{~g}$ Aq extract (10\%). ${ }^{15}$

\section{Drugs and reagents}

Chemicals and reagents used included methanol, paracetamol syrup $125 \mathrm{mg} / 5 \mathrm{~mL}$, Brewer's yeast, gum acacia and normal saline. All the reagents and chemicals used were of analytical grade and were directly purchased from Merck Sdn Bhd, Kuantan. Paracetamol syrup $125 \mathrm{mg} / 5 \mathrm{~mL}$ (GlaxoSmithKline) was obtained from Lim Pharmacy, Kuantan.

\section{Phytochemical screening}

Phytochemical screening for methanolic $(\mathrm{MeOH})$ and aqueous (Aq) extracts of $T$. dependens leaves was carried out qualitatively for the presence of different class of biologically active compounds viz. tannins, steroids, terpenoids, flavonoids, phenolics, saponins, alkaloids and glycosides. ${ }^{15}$

\section{Experimental animals}

Healthy albino mice (Institute of Cancer Research (ICR) strain, USA) of either sex weighing 28-36 g were used in this study and obtained from the Sapphire Enterprise, Selangor, Darul Ehsan Malaysia. The animals were housed in disinfected metal cages padded with saw dust, placed on metal shelves in a fully ventilated room at controlled temperature $\left(25 \pm 2^{\circ} \mathrm{C}\right)$ and maintained in a 12 hour dark-light cycle. The mice were given free access to feed and clean tap water ad libitum. The drinkers containing clean tap water for the animals were washed and refilled daily. The use of experimental mice was permitted by the Institutional Animal Care \& Use Committee (IACUC-IIUM), Kuantan. Ethics clearance for the in vivo experimental work was obtained from the IACUC-IIUM prior to experimental procedure.

\section{Acute toxicity study of $\mathrm{Aq}$ and $\mathrm{MeOH}$ extracts of the} leaves of $T$. dependens

A separate experiment was conducted to know whether any toxic effect could be produced by $\mathrm{Aq}$ and $\mathrm{MeOH}$ extracts of the leaves on normal healthy albino mice of either sex. The mice were allowed to acclimatize for a period of 7 days before the determination of $\mathrm{LD}_{50}$ which was carried out according to the method of Organisation for Economic Co-operation and Development (OECD) guidelines. ${ }^{16}$ All mice starved for $12 \mathrm{~h}$ were randomly divided into two groups $(n=10)$ and were fed orally with both Aq and $\mathrm{MeOH}$ extracts separately starting with the graded doses of 100,500 and $1000 \mathrm{mg} / \mathrm{kg}$ body weight (b.w.), respectively. Animals were dosed individually and observed continuously for $24 \mathrm{~h}$ and their behavioural and neurological changes were vigilantly observed for any sign of acute toxicity by following up and down 
method (OECD) ${ }^{16}$ All mice were allowed to pellet diet and tap water ad libitum, and the mortality caused by the extracts within this period of time was also observed. Any acute toxic symptoms were observed and recorded systematically in 1, 2, 4, 6 and 24 hours after extract administration. The number of animals that survived or died in each group within 24 hours was observed and recorded. The observation of acute toxic symptoms included but is not limited to skin changes, restlessness and aggressiveness, rubbing of mouth and nose on the surface of the cage, sensitivity to sound and pain, as well as respiratory movements and sedation. The acute toxic effect of the extract was assessed on the basis of mortality, which was expressed as $L D_{50}$. Finally the $L_{50}$ value was determined as the arithmetical mean of the highest non-lethal dose (with no deaths) and the lowest lethal dose (where if deaths happened).

\section{Induction of pyrexia}

The animals were allowed an acclimatization period of 7 days before the commencement of experiment for the evaluation of antipyretic activity to be carried out. Fever was induced by a subcutaneous injection of $10 \mathrm{ml} / \mathrm{kg}$ b.w. of $15 \%(\mathrm{w} / \mathrm{v})$ yeast suspended in $0.5 \%(\mathrm{w} / \mathrm{v})$ methylcellulose solution. Mice were then carefully put back to their housing cages and initial rectal temperatures of the experimental animals were recorded with the help of clinical thermometer by inserting it $1.5 \mathrm{~cm}$ deep into the rectum, and holding it in place for one minute. This was done in order to ensure that the mice were normothermic before administering the brewer's yeast. After 18 hours, the rectal temperature of the mice were determined via the same procedure and recorded. Animals that indicated a rise in body temperature of at least 0.6 ${ }^{\circ} \mathrm{C}$ were considered eligible for carrying out further experiments. ${ }^{17}$

\section{Antipyretic activity}

Thirty-six experimental animals eligible for the experiment were randomly divided into 6 groups of 6 mice each $(\mathrm{n}=6)$. Group I received $5 \mathrm{ml} / \mathrm{kg}$ body weight of $2 \%(\mathrm{v} / \mathrm{v})$ aqueous normal saline solution orally (vehicle control group), as negative control. Group II received standard drug viz. paracetamol $150 \mathrm{mg} / \mathrm{kg}$ body weight orally. Groups III and IV received $\mathrm{MeOH}$ extract and groups $\mathrm{V}$ and $\mathrm{VI}$ received Aq extract orally at 100 and $200 \mathrm{mg} / \mathrm{kg}$ body weight, respectively. The $\mathrm{MeOH}$ extract prepared in the form of emulsion (oil: water, 6:4) and Aq extract in double-distilled sterilized water, were administered to the experimental animals by gastric intubation using forced feeding needle. Temperature was noted down at $1 \mathrm{~h}$ intervals up to $22 \mathrm{~h}$ after giving yeast injection and the rectal temperatures of the mice were recorded at $0,1,2$, 3 and 4 hours. ${ }^{17}$ The percent reduction in pyrexia was calculated by the following formula: Percent reduction $=\mathrm{B}-\mathrm{Cn} / \mathrm{B}-\mathrm{A} \times 100$; Where, $\mathrm{B}$ represents temperature after pyrexia induction; $C n$ temperature after $0,1,2$, 3 and $4 \mathrm{~h}$ and $\mathrm{A}$ represents normal body temperature. ${ }^{17}$ Statistical analysis. The data values were shown as mean \pm standard error of mean (S.E.M) and analysed using one way ANOVA followed by Dunnett's test. $P$ values less than 0.05 were considered statistically significant.

\section{RESULTS AND DISCUSSION}

Phytochemical analysis

Dried leaves of $T$. dependens yielded $40 \mathrm{~g}(8 \%)$ and 20 g (10\%) methanol $(\mathrm{MeOH})$ and aqueous (Aq) extracts, respectively. Phytochemical screening revealed for the occurrence of saponins, flavonoids, tannins and phenolic compounds as biochemical constituents in appreciable amount in $\mathrm{MeOH}$ extract. However, Aq extract revealed for the presence of phenolics, saponins and glycosides only. Both extracts showed negative results for the presence of alkaloids as well as cardiac glycosides. The results are shown in Table I.

Table I.Preliminary phytochemical analysis of methanolic $(\mathrm{MeOH})$ and aqueous $(\mathrm{Aq})$ extracts of Thottea dependens leaves

\begin{tabular}{|c|c|c|c|}
\hline \multicolumn{2}{|c|}{ Chemical analysis } & \multirow{2}{*}{$\begin{array}{c}\mathrm{MeOH} \text { extract of leaves } \\
+++\end{array}$} & \multirow{2}{*}{$\begin{array}{l}\text { Aqueous extract of le } \\
+\end{array}$} \\
\hline Phenolics & $\mathrm{FeCl}_{3}$ test & & \\
\hline & Lead acetate test & +++ & + \\
\hline \multirow[t]{3}{*}{ Flavonoids } & $\mathrm{NaOH}$ test & +++ & - \\
\hline & Shinoda test & +++ & - \\
\hline & $\mathrm{H}_{2} \mathrm{SO}_{4}$ test & +++ & - \\
\hline \multirow[t]{3}{*}{ Alkaloids } & Dragendorff's test & - & - \\
\hline & Wagner's test & - & - \\
\hline & Mayer's test & - & - \\
\hline \multirow[t]{2}{*}{ Tannins } & Ferric chloride test & ++ & - \\
\hline & Gelatin test & + & - \\
\hline Saponins & Foam test & +++ & + \\
\hline Steroids & Liebermann test & + & - \\
\hline Terpenoids & Salkowski test & + & - \\
\hline \multirow[t]{2}{*}{ Glycosides } & Borntrager's test & + & ++ \\
\hline & Legal's Test & - & - \\
\hline
\end{tabular}

Note: +++ (good intensity); ++ (moderate intensity); + (weak intensity); - (absence) 
Acute toxicity study of $\mathrm{Aq}$ and $\mathrm{MeOH}$ extracts of the leaves of $T$. dependens

Acute toxicity study clearly revealed the non-toxic and safe nature of both $\mathrm{MeOH}$ as well as Aq extracts of the leaves of $T$. dependens. Nomortality was observed in the extracts treated mice and behavior of the treated mice also appeared normal in most of the animals. Neither lethality nor any toxic reactions were found at any dose selected until the completion of the study. The $\mathrm{LD}_{50}$ of the $\mathrm{Aq}$ and $\mathrm{MeOH}$ extracts as per OECD guidelines falls under class 4 , as no signs of acute toxicity and mortality were observed up to $1000 \mathrm{mg} / \mathrm{kg}$ b.w. Hence, the dosages for both extract to determine antipyretic activity were fixed at $100 \mathrm{mg} / \mathrm{kg} \mathrm{b.w.} \mathrm{and}$ $200 \mathrm{mg} / \mathrm{kg}$ b.w., respectively.

\section{Antipyretic activity}

It was witnessed that the $\mathrm{MeOH}$ extract at $200 \mathrm{mg} /$ $\mathrm{kg}$ b.w. instigated lowering in normal rectal body temperature up to $4 \mathrm{~h}$ following its administration.
This effect was highest at $4 \mathrm{~h}$ (Table II). It was found that the subcutaneous injection of yeast suspension distinctly elevated the rectal temperature of mice following $18 \mathrm{~h}$ of its administration. Standard drug paracetamol (150 mg/ kg b.w.) reduced the yeastinduced elevation of body temperature. However, at $100 \mathrm{mg} / \mathrm{kg}$ b.w., MeOH extract had no effect in reducing the temperature. The same results were manifested by Aq extract at 100 and 200 mg/kg b.w., whereby no temperature subsiding was observed.

Among six groups, standard Paracetamol $(150 \mathrm{mg} / \mathrm{kg}$ b.w.) and $\mathrm{MeOH}$ extract of $200 \mathrm{mg} / \mathrm{kg} \mathrm{b.w.} \mathrm{showed}$ temperature reduction by more than $20 \%$. Based on the result and analysis, $\mathrm{MeOH}$ extract at $200 \mathrm{mg} / \mathrm{kg}$ b.w. significantly exhibited antipyretic activity but not at lower dose viz. $100 \mathrm{mg} / \mathrm{kg}$ b.w. However, Aq extract at both doses viz. 100 and $200 \mathrm{mg} / \mathrm{kg}$ b.w. did not show any antipyretic effect in mice.

Table II: Antipyretic effect of methanolic and aqueous extract of Thottea dependens leaves on mice induced hyperthermia.

\begin{tabular}{|c|c|c|c|c|c|c|c|c|}
\hline \multirow[t]{2}{*}{ Group } & \multirow[t]{2}{*}{ Treatment } & \multirow{2}{*}{$\begin{array}{l}\text { Dose, } \\
\mathrm{mg} / \mathrm{kg} \\
\text { b.w. }\end{array}$} & \multirow{2}{*}{$\begin{array}{l}\text { Initial } \\
\text { Rectal } \\
\text { Temp. in }{ }^{\circ} \mathrm{C} \\
\text { before Yeast } \\
\text { Injection }\end{array}$} & \multicolumn{5}{|c|}{$\begin{array}{l}\text { Rectal Temperature in }{ }^{\circ} \mathrm{C} \text { after } 18 \mathrm{~h} \text { of Yeast } \\
\text { Injection }\end{array}$} \\
\hline & & & & Ohr & $1 \mathrm{hr}$ & $2 \mathrm{hr}$ & $3 \mathrm{hr}$ & $4 \mathrm{hr}$ \\
\hline I & $\begin{array}{l}\text { Normal } \\
\text { Saline }\end{array}$ & $\begin{array}{l}5 \mathrm{~mL} / \\
\mathrm{kg}\end{array}$ & $\begin{array}{l}37.75 \pm \\
0.33\end{array}$ & $\begin{array}{l}38.67 \pm \\
0.38\end{array}$ & $\begin{array}{l}38.83 \pm \\
0.41\end{array}$ & $\begin{array}{l}39.17 \pm \\
0.33\end{array}$ & $\begin{array}{l}38.90 \pm \\
0.49\end{array}$ & $\begin{array}{l}38.90 \pm \\
0.4\end{array}$ \\
\hline II & $\begin{array}{l}\text { Standard } \\
\text { Paracetamol }\end{array}$ & $\begin{array}{l}150 \\
\mathrm{mg} / \mathrm{kg}\end{array}$ & $\begin{array}{l}37.18 \pm \\
0.75\end{array}$ & $\begin{array}{l}38.08 \pm \\
0.32\end{array}$ & $\begin{array}{l}37.7 \pm \\
0.43^{*}\end{array}$ & $\begin{array}{l}37.48 \pm \\
0.47^{*}\end{array}$ & $\begin{array}{l}37.58 \pm \\
0.43^{*}\end{array}$ & $\begin{array}{l}37.8 \pm \\
0.47^{*}\end{array}$ \\
\hline III & $\begin{array}{l}\mathrm{MeOH} \\
\text { extract }\end{array}$ & $\begin{array}{l}100 \\
\mathrm{mg} / \mathrm{kg}\end{array}$ & $\begin{array}{l}37.38 \pm \\
0.23\end{array}$ & $\begin{array}{l}38.57 \pm \\
0.47\end{array}$ & $\begin{array}{l}38.57 \pm \\
0.56\end{array}$ & $\begin{array}{l}38.63 \pm \\
0.33\end{array}$ & $\begin{array}{l}38.85 \pm \\
0.57\end{array}$ & $\begin{array}{l}38.83 \pm \\
0.50\end{array}$ \\
\hline IV & $\begin{array}{l}\mathrm{MeOH} \\
\text { extract }\end{array}$ & $\begin{array}{l}200 \\
\mathrm{mg} / \mathrm{kg}\end{array}$ & $\begin{array}{l}37.63 \pm \\
0.30\end{array}$ & $\begin{array}{l}38.58 \pm \\
0.43\end{array}$ & $\begin{array}{l}38.23 \pm \\
0.37\end{array}$ & $\begin{array}{l}38.10 \pm \\
0.60\end{array}$ & $\begin{array}{l}37.97 \pm \\
0.52^{*}\end{array}$ & $\begin{array}{l}37.75 \pm \\
0.66^{*}\end{array}$ \\
\hline V & Aq extract & $\begin{array}{l}100 \\
\mathrm{mg} / \mathrm{kg}\end{array}$ & $\begin{array}{l}36.18 \pm \\
1.12\end{array}$ & $\begin{array}{l}38.33 \pm \\
0.37\end{array}$ & $\begin{array}{l}39.02 \pm \\
0.44\end{array}$ & $\begin{array}{l}38.85 \pm \\
0.30\end{array}$ & $\begin{array}{l}38.72 \pm \\
0.40\end{array}$ & $\begin{array}{l}38.83 \pm \\
0.39\end{array}$ \\
\hline VI & Aq extract & $\begin{array}{l}200 \\
\mathrm{mg} / \mathrm{kg}\end{array}$ & $\begin{array}{l}36.8 \pm \\
0.58\end{array}$ & $\begin{array}{l}38.33 \pm \\
0.19\end{array}$ & $\begin{array}{l}38.65 \pm \\
0.34\end{array}$ & $\begin{array}{l}38.68 \pm \\
0.48\end{array}$ & $\begin{array}{l}38.78 \pm \\
0.43\end{array}$ & $\begin{array}{l}38.85 \pm \\
0.52\end{array}$ \\
\hline
\end{tabular}

Data are reported as mean \pm S.E.M. for group of six animals. The data was analyzed by ANOVA followed by Dunnett'stest. Asterisks $\left({ }^{*}\right)$ indicated statistically significant values from control. ${ }^{*} P<0.01$.

\section{DISCUSSION}

Plants have been used for centuries for medicinal purposes by various cultures and ethnicities around the world and continue to be important curative agents for various disorders even with the revolution in antibiotics and other synthetic agents in modern scientific world. Different mechanisms of action of phytoconstituents from medicinal plants have been proposed. They may impede different metabolic processes or may modify gene expression and signal transduction pathways or may obstruct microorganisms' growth. ${ }^{18}$ Non-steroidal anti-inflammatory drugs (NSAIDs) are among the most commonly prescribed drugs owing to their unswerving effectiveness in the treatment of pain, fever, inflammation and rheumatic disorders. ${ }^{19}$ Since these drugs have toxic effect to the various organs of the body, a search for safe drugs especially safe herbal remedies with potent antipyretic activity has received great momentum recently. ${ }^{20}$ Fever is a multifaceted 
physiologic response elicited by aseptic stimuli or various infections. Rise in body temperature arises when the concentration of prostaglandin E2 (PGE2) upsurges inside the hypothalamic region of the brain. Such an elevation creates substantial alteration in the firing degree of neurons that regulate the thermoregulation process in the hypothalamus. ${ }^{21}$ It is now evident that most of the antipyretic drugs manifest their effect by impeding the enzymatic activity of cyclooxygenase and subsequently decrease the levels of PGE2 within the hypothalamic region of brain. ${ }^{22} \mathrm{~A}$ natural antipyretic agent with less or no toxicity is therefore, considered vital. ${ }^{23}$ Since antipyretic activity is normally cited as a characteristic of drugs or agents, which possess an inhibitory property on prostaglandins biosynthesis, the yeast induced hyperpyrexia in rat model was employed to determine the antipyretic effect of $\mathrm{MeOH}$ and $\mathrm{Aq}$ extracts of the leaves of T. dependens. Yeast induced pyrexia is known as pathogenic fever which is elicited because of the formation of prostaglandins (PGE2) that regulate the thermoregulatory center at an elevated temperature. ${ }^{24}$

T.dependens, which possess the biologically active phytoconstituents like flavonoids, steroids, saponins and terpenoids is an important medicinal plant indigenous to South Asian countries, whose medicinal properties are reported in traditional systems of medicine. ${ }^{13,14}$ The current study was carried out to evaluate and compare the in vivo antipyretic activity of the $\mathrm{MeOH}$ and Aq extracts of the leaves of $T$. dependens by yeast induced pyrexia method. The results showed that $\mathrm{MeOH}$ extract possesses a significant antipyretic effect in yeast induced elevation of body temperature in experimental mice. It was observed that the extract shows dose dependent antipyretic activity. At a dose of $200 \mathrm{mg} / \mathrm{kg}$ b.w., it showed significant antipyretic activity. At this concentration, normalization of body temperature was maintained for sufficient period of time. Flavonoids are known to target prostaglandins which are involved in the pyrexia. These polyphenolics have been reported to elicit antipyretic action through inhibiting arachidonic acid peroxidation as well as subduing TNF- $a$, which result in reduction of prostaglandin levels thus helping to reduce the fever and pain. ${ }^{25}$ Hence, the presence of greater amount of flavonoids in the methanolic extract of $T$. dependens leaves might be responsible for its antipyretic activity. The $\mathrm{MeOH}$ extract showed more pronounced effect in lowering the hyperthermia than the Aq extract, but found to have similar effect as the standard drug paracetamol at 3rd hour of administration. The extract is likely to reduce pyrexia by decreasing brain concentration of prostaglandin E2 especially in the hypothalamus owing to its effect on COX-3 or by augmentation of the production of the body's own antipyretic substances like arginine and vasopressin. ${ }^{26}$ Antipyretics have been reported to subdue fever by retarding the activity of prostaglandin synthetase, resulting in the blockade of the synthesis of prostaglandin in the brain or subduing the escalation of interleukin- 1a production subsequent to interferon production. ${ }^{27}$ This study also correlates with the study that suggested about flavonoids and saponins to act synergistically to exert the antipyretic effect. ${ }^{28}$ The results of present study indicate that the $\mathrm{MeOH}$ extract of $T$. dependens leaves possesses significant antipyretic activity compared to the activity of Aq extract on yeast induced hyperthermia in mice. This could be credited for the presence of flavonoids and saponins in leaves that might be responsible for the inhibition of prostaglandin synthesis. Moreover, there are several intermediaries accentuating the pathogenesis of fever. Reducing the activity of these intermediaries could further reduce fever significantly.

\section{CONCLUSION}

$\mathrm{MeOH}$ extract of $T$. dependens leaves at higher dose do exhibit antipyretic activity and provides evidences for the antipyretic activity of $T$. dependens which could partly contribute to its traditional medicinal use. However, further investigation is still required to isolate the active constituents responsible for the antipyretic activity as well as to elucidate the exact mechanism of action.

\section{CONFLICT OF INTEREST}

All authors declare no conflict of interest.

\section{ACKNOWLEDGEMENT}

We particularly wish to thank the traditional practitioners and field supervisors who helped to collect the plant material. The authors would like to gratefully acknowledge to RMC, IIUM for an endowment fund research grant (EDW B 12-366-0844). Authors also gratefully acknowledge the use of laboratory facilities in the Department of Pharmaceutical Chemistry and Animal House, IIUM.

\section{REFERENCES}

1. Sullivan JE, Farrar HC. Fever and antipyretic use in children. Pediatrics 2011; 127:580-7.

2. Kiekkas P, Aretha D, Bakalis N, Karpouhtsi I, Marneras C, Baltopoulos GI. Fever effects and treatment in critical care: literature review. Aust Crit Care 2013; 26:130-5.

3. Lee A, Cooper MG, Craig JC, Knight JF, Keneally JP. Effects of nonsteroidal anti-inflammatory drugs on postoperative renal function in adults with normal renal function. Cochrane Database Syst Rev 2007; 2:CD002765.

4. Hinson JA, Roberts DW, James LP. Mechanisms of acetaminophen-induced liver necrosis. Handb Exp Pharmacol 2010; 196:369-405.

5. Sun SX, Lee KY, Bertram CT, Goldstein JL. Withdrawal of COX-2 selective inhibitors rofecoxib and valdecoxib: impact on NSAID and gastroprotective drug prescribing and utilization. Curr Med Res Opin 2007; 23:1859-66.

6. Philip AM. Antipyretic Therapy's Future. Clin Infect Dis 2000; 31(S5): S242-S243.

7. Ramarao AV, Gunjar MK. Drugs from plant 
resources an overview. Pharma Times 1990;

22:19-27.

8. Martins Ekor. The growing use of herbal medicines: issues relating to adverse reactions and challenges in monitoring safety. Front Pharmacol 2013; 4:177.

9. World Health Organization. National Policy on Traditional Medicine and Regulation of Herbal Medicines. Report of a World Health Organization Global Survey. Geneva, Switzerland 2005.

10. Shah BN, Seth AK. Medicinal plants as a resource of antipyretics agent: A review. Adv Biores 2010; 1:10-6.

11. World Health Organization. World Health Organization Guidelines on Safety Monitoring of Herbal Medicines in Pharmacovigilance Systems. Geneva, Switzerland 2004.

12. Rates SM. Plant as a source of drug. Toxicon 2001; 39:603-13.

13. Faridah $\mathrm{H}$, Nurulhuda $\mathrm{H}$. The use of medicinal plant species by the Temuan Tribe of Ayer Hitam Forest, Selangor, Peninsular Malaysia. Pertanika J Trop Agric Sci 1999; 22:85-94.

14. Wiart, C. Medicinal plants of Southeast Asia. 2nd edition. Prentice Hall, Pearson Malaysia Sdn. Bhd, Selangor, Malaysia 2002

15. Harbone JB. Phytochemical Methods: A Guide to Modern Techniques of Plant Analysis. 3rd edition. Chapman and Hall, London, UK 1998.

16. Organization for Economic Co-operation and Development (OECD). OECD guidelines for the testing of chemicals. Test No. 425: Acute Oral Toxicity: Up-and-Down Procedure. October 2008.

17. Naveed M, Saeed M, Haroon K. Antipyretic, analgesic and anti-inflammatory activity of Viola betonicifolia whole plant. BMC Complement Altern Med 2012; 12:59.

18. Umar A, Ahmed QU, Muhammad BY, Dogarai BBS, Siti ZMS. Antihyperglycemic activity of the leaves of Tetracera scandens Linn. Merr.

(Dilleniaceae) in alloxan induced diabetic rats. J Ethnopharmacol 2010; 131:140-5.

19. Solomon DH, Schneeweiss S, Glynn RJ, et al. Relationship between selective cyclooxygenase-2 inhibitors and acute myocardial infarction in older adults. Circulation 2004; 109:2068-73.

20. Ray WA, Stein CM, Daugherty JR, et al. COX-2 selective non-steroidal anti-inflammatory drugs and risk of serious coronary heart disease. Lancet 2002; 360:1071-3.

21. Simmons DL, Botting RM, Hla T. Cyclooxygenase isozymes: the biology of prostaglandin synthesis and inhibition. Pharmacol Rev 2004; 56:387-437.

22. Moltz H. Fever: causes and consequences. Neurosci Biobehav Rev 1993; 17(3):237-69.

23. Germain ST, Elisabeth NB, Theophile D, Emmanuel T et al. Antipyretic and antinociceptive effects of Nauclea latifolia roots decoction and possible mechanisms of action. Pharm Biol 2011; 49:15-25.

24. Warner T, Mitchell JA. Cyclooxygenase-3 (COX-3): Filling in the gaps toward a COX continuum?. Proc Natl Acad Sci USA 2002; 99:13371-3.
25. Rajnarayana K, Reddy MS, Chaluvadi MR, Krishna DR. Bioflavonoids classification, pharmacological, biochemical effects and therapeutic potential. Indian. J Pharmacol 2001; 33:2-16.

26. Jude EO, Paul N. Antiinflammatory, analgesic and antipyretic activities of ethanol root extract of Croton zambesicus. Pak J Pharm Sci 2010; 23:385-392.

27. Steiner AA, Ivanov Al, Serrats J, Hosokawa H et al. Cellular and molecular bases of the initiation of fever. PloS Biol 2006; 4:e284.

28. Zakaria Z, Loo YW, Nurul IAR, Abdul HAAet al. Antinociceptive, anti-Inflammatory and antipyretic properties of the aqueous extract of Bauhinia purpurea leaves in experimental animals. Med Princ and Pract 2007; 16:443-449. 